\title{
Communication Strategy of Aceh Government to Handling Covid-19 Pandemic in Aceh Province
}

\author{
Nadhar Putra ${ }^{1}$, Syailendra Reza Irwansyah Rezeki ${ }^{2}$, Yuliana Restiviani ${ }^{3}$ \& Rita Zahara ${ }^{4}$ \\ ${ }^{1,4}$ Universitas Islam Negeri Sumatera Utara, Indonesia, ${ }^{2}$ Politeknik Pariwisata Batam, Indonesia, \& ${ }^{3}$ Institut Agama \\ Islam Negeri Lhokseumawe, Indonesia
}

\begin{tabular}{|c|c|}
\hline ARTICLE INFO & \multirow{14}{*}{$\begin{array}{l}\text { Corona Virus Disease } 2019 \text { or Covid-19 that firstly identified in } \\
\text { Wuhan-China rapidly spreaded to } 215 \text { countries over the world and } \\
\text { has not ended yet. In Indonesia, the first Covid-19 outbreak case was } \\
\text { on March } 2020 \text { and also has spread rapidly to all provinces. Aceh is } \\
\text { noted to be more successful in dealing with the pandemic compared } \\
\text { to other provinces. Aceh achieved appreciation from central } \\
\text { government and asked to share successful experiences with other } \\
\text { provinces. This study is aimed to identify and analyze the } \\
\text { Communication Strategy applied by Aceh Government and the } \\
\text { challenges faced while handling the Covid-19 Pandemic in Aceh. } \\
\text { This descriptive-analytic research uses interview, observation and } \\
\text { documentation study techniques as data collection techniques. } \\
\text { Furthermore, the data is processed using Constant Comparative } \\
\text { Techniques and Domain Analysis in order to obtain relatively valid } \\
\text { conclusions. The results of the study concluded that there were } 4 \\
\text { (four) Communication Strategies implemented by the Aceh } \\
\text { Government, namely: Motivational Communication Strategy, Quick } \\
\text { Response Strategy, Leadership Commitment Communication } \\
\text { Strategy and Mass Communication Strategy. Meanwhile, there are } \\
\text { various challenges faced by the Aceh Government in implementing a } \\
\text { communication strategy while handling the Covid-19 pandemic, that } \\
\text { is; Regional Accessibility, Socio-Economic, Socio-Cultural and } \\
\text { Religious as well as Local Political Dynamics. }\end{array}$} \\
\hline Article history: & \\
\hline Received Dec 30, 2020 & \\
\hline Revised Jan 30, 2021 & \\
\hline Accepted Feb 27, 2021 & \\
\hline Keywords: & \\
\hline Communication Strategy, & \\
\hline Aceh Government, & \\
\hline & \\
\hline Conflict of Interest: & \\
\hline None & \\
\hline Funding: & \\
\hline Fring. & \\
\hline None & \\
\hline
\end{tabular}

Corresponding Author: Nadhar Putra, Universitas Islam Negeri Sumatera Utara, Medan, Sumatera Utara 20143, Indonesia. E-mail: nadhar1607@gmail.com.

(C) (C) This is an open access article under the CC BY-SA 4.0 international license.

\section{Introduction}

Since the beginning of its spread in Hubei, China on December 2019, the Corona Virus or known as Covid19 has rapidly spread around the world. This virus that firstly identified in Wuhan-China, at the end of August 2020 has rapidly spreaded to 215 countries with a total number of infected victims of 25,382,745 people, 850,503 died and 17,704,831 people declared cured (worldometers, 2020). The world health institution, WHO, led by Tedros Adhanom Ghebreyesus on January 30, 2020 initially declared Covid-19 only as an epidemic or Global Health Emergency. However, seeing the very fast transmission almost all over the world, finally on March 11, 2020 WHO declared the Corona Virus as Global Pandemic and appealed countries in the world to take urgent and aggressive action in preventing the spread of Covid-19. (who.com, 2020).

Although other countries have been busy with the number of Covid-19 cases in their country, Indonesia has just announced its first case on March 2, 2020. President Joko Widodo announced himself from the State 
Palace there has been 2 patients stated infected with the covid-19 virus in Indonesia. Jokowi said, the mother and daughter had interacted with a Japanese who had been infected with the corona virus when visited Indonesia (nasionalkompas.com, 2020). After the announcement, almost all news programs in mass media filled with information about additional case of Covid-19 patients as well as the rapid spread throughout Indonesia. Effective until the end of August 2020, the data shows that Covid-19 cases in Indonesia have reached a total of 174,796 positive cases; with 7,417 people died and 125,959 people recovered. This number increased significantly compared to its first case on March 2, 2020. In just 6 (six) months, cases of Covid-19 have reached more than 100,000 patients. (covid19.go.id, 2020).

Aceh, as a province in the westernmost part of Indonesia, cannot be spared from the Covid-19. The data shows, effective until the end of August 2020 there are 1.545 positive cases in Aceh; with 57 people died and 602 people recovered. (dinkes.acehprov.go.id, 2020). Most of the residents that were confirmed positive Covid-19 had a history of travel from other areas, and only a few people who are infected from local transmission. Based on this data, if compared to other provinces in the country, Aceh is a province with a relatively small number of positive Covid-19 cases. This is based on the results of comparisons with 22 other provinces in Indonesia, which shows that Aceh ranks 12th out of 34 Provinces with the lowest number of positive Covid-19 cases in Indonesia. This figure is a positive number for Covid-19 case after Aceh experienced the First and Second Wave of the spread of this deadly virus. The First Wave occurred since the establishment of the Emergency Response period by the Government through the BNPB, which began on January 28, 2020 until 23 April 2020. At that time, Acehnese who were in other provinces, even from Malaysia (also a pandemic country near Aceh) returned to Aceh because of the establishment of Large-Scale Social Restrictions (PSBB), even lockdowns policy by the Regional / Local Government. The Second Wave occurred when entering the fasting month of Ramadan, when the celebration of Eid Fitr and Eid Adha in 2020. Because at that time may had been a mobilization of citizens who returned home to enjoyed Ramadan and celebrated Eid in their hometown. This high level of citizen mobilization has significantly increased the spread of Covid-19. This is very influential, since the spread of Covid-19 requires a medium or carrier (infected human) to move from one to another person.

The academics and practitioners as well as mass organizations those who care about health in Aceh, including Management of the Indonesian Doctors Association (IDI) for Aceh region, previously had predicted the addition of positive cases Covid-19 significantly in the second wave (aceh.tribunnews.com, 2020). Their predictions were proven after July 30, 2020, Aceh Province noted the addition of 45 positive Covid-19 case. These 45 cases are the highest number of increases that have occurred for the first time in Aceh. Data also shows that Covid-19 has spread to nearly 23 districts / cities in Aceh. From then on, the number of positive Covid-19 cases continued to grow and attained 168 cases on August 17, 2020. (dinkes.acehprov.go.id, 2020). Predictions from IDI are now very accurate compared with predictions of the first wave (early March - May 2020) Aceh still has the lowest number of positive Covid-19 case and the most successful province that suppressed the spread of Covid-19 both in terms of prevention and treatment to the victims. No doubt, on 27 May 2020 the Head of the National Agency for Disaster Management (BNPB) in Jakarta as Chair of the Indonesian Covid-19 Accelerated Handling Task Force sent an official letter to Aceh Government asked to share Success Experiences related to Covid-19 Handling strategies for other provinces in Indonesia (aceh.tribunnews.com, 2020).

Based on authors'observation, the concern of academics, activists, mass-organizations and health practitioners about the increasing number of positive Covid-19 cases in Aceh is reasoned. If we look at regional accessibility, Aceh has big potential for the spread of the Covid-19 virus. Access by land, sea and air provides an opportunity for anyone to entering Aceh. Likewise, several socio-cultural, socio-economic, socio-political and religious conditions have the potential to gave way for the spread of Covid-19. These conditions are big challenges in handling Covid-19.

The Aceh Government through the Aceh Covid-19 Accelerated Handling Task Force as the most responsible institution for handling Covid-19 has taken many quick and important steps, and announced to the public. Seeing those considerable challenges, coupled with the fake news attacks (negative campaigns) about the handling of Covid-19 on social media, the Aceh Government has communication strategies specially to reinforce the Covid-19 control program. (humas.acehprov.go.id, 2020). From the first data obtained, several actions by the Aceh Government in fighting Covid-19 received appreciation from the Central Government and foreign parties. Several main themes were spread in public communication activities to get sympathy and support from the people of Aceh, to fight Covid-19 together. Among the main themes published, the most interesting one is a sentence that begins with a hashtag, namely \#AcehLawanCovid19. This hashtag is very inspiring to authors and will make it a highlight or main analysis in this paper. 
Since these are all big challenges, communication strategies are very important. Due to handling this pandemic, the citizens' participation and active role will determine success. Communication is the best stategy to successing disaster mitigation. Good public, government, media, and leaders-opinion communication can reduce risks, saving lives and reducing impact of disasters (Haddows, 2020, p. 7). Communication activities will run effectively if the communicator understands the culture of the communicant. A good communication strategy has won at least half of the battle, in this case, against the global Covid-19 pandemic (Chrosky, 2020, p. 62).

Based on these facts, the authors found indications of a communication strategy adopted by the Government of Aceh in handling Pandemic Covid-19. It can be seen from the publication of data and information on social media, news from local and national newspapers, the daily online as well as data and information published officially in the pages Aceh government's official website. Therefore, the authors is interested in revealing all these phenomena through a study entitled \#AcehLawanCovid19, that is Communication Strategy Of Aceh Government To Handling Covid-19 Pandemic In Aceh Province.

Problems of this research are; How is the Communication Strategy of Aceh Government while Handling Covid-19 in Aceh Province and how are the Challenges faced by the Aceh Government in implementing the Communication Strategy while Handling Covid-19? While the expected benefits are: theoretically, this paper is written to enriching science which useful for society, campus community, academics, researchers and writers themselves. Practically, this paper is expected to be a role model for handling outbreaks or other pandemics in the future of Aceh Province. The focus model is on the implementing a Communication Strategy adapted to the situation and conditions in Aceh, so that various handling efforts can be successful. Besides the Aceh Government, this Communication Strategy model can also be adopted by other Provincial Governments in Indonesia which have the same or similar characteristics as Aceh.

\section{Literature Review}

\subsection{Communication Strategy}

\subsubsection{The Definition of Communication Strategy}

According to Onong Uchyana Effendi, strategy is basically planning and management to achieve a goal. However, to achieve the goal, the function of strategy is not as a road map that only shows directions, but must be able to show operational tactics. Likewise, a communication strategy is a combination of communication planning with communication management to achieve predetermined goals. This communication strategy must be able to show how practical operations should be carried out, in the sense that the approach can be different from time to time depending on the situation and conditions (Effendi, 1990, p. 32). Success or failure of communication really depends on the strategy. Without communication strategy, even the most modern mass media will not achieve its objectives well.

The communication strategy is a technique or way for delivering a message that is considered effective to the audience to give the effect as expected. The messages received by the audience at the same time not only from one source, because it takes a special strategy to surpass the struggle so that it can effectively achieve the goals expected change of attitude (Fajar, 2009, p. 183).

The communications strategy is also intended as a technique or method of communication designed the communicator so that the messages successfully or effectively achieve the expected goals, both, quantitatively which includes targets a wide audience, and qualitatively in which the messages to be well received by the target audience as expected. A message is considered effective and has qualitative value, if the message is received and has the effect of a significant change in the attitude of the target audience. Meanwhile, communication expert Middleton, as quoted by Hafied Cangara, defines a communication strategy as the best combination of all communication elements ranging from communicators, messages, channels, receivers to influences designed to achieve optimal communication goals. Strategy selection is a crucial step that requires careful treatment in communication planning, because the results can be fatal if the strategy is wrong then, especially losses in terms of time, material and energy. (Cangara, Perencanaan dan Strategi Komunikasi, 2007, p. 2).

Strategy is always needed in a communication plan, in order to achieve the highest level of effectiveness, in marketing communications, development communications, and campaigns for certain programs, whether on an international, regional, national or local scale. At first, these programs run dynamic because it is supported by a major grant. But when the funds run out, the program ended. These conditions are often found in third world countries, where the program is done simply to make personal gain (corruption). Eventually, the program supported by large funds became failed. But behind the failure, there are many communication 
program was implemented fairly successful, including the marketing of fertilizers Azola in the Philippines, the revolution in agricultural production in Indonesia, the campaign against drunk for drivers in North America, the campaign energy savings in electricity in Canada, the campaign participation of the population in the Village Bank program in Bangladesh, etc. So, the success of a communication or development program that requires communication support, basically depends on the planning itself. (Cangara, Perencanaan dan Strategi Komunikasi, 2007, p. 2).

Study of communication planning, initially emerged from the conflict of interest between developing countries and developed countries which peaked in the 1970s, especially regarding the imbalance of information. Distribution of information around the world is considered unfair, developed countries which have the power of communications technology transferring various information to developing countries which are less able to buy information technology. The imbalance of information is also evidenced by Gebner's research on 60 newspapers from 9 countries (3 capitalist countries, 3 socialist countries and 3 developing countries) that found the newspapers published in capitalist and socialist countries have measly news from developing countries. Even if there is news about developing countries, only negative news, such as conflict, poverty, riots, hunger, ignorance, etc. (Cangara, Perencanaan dan Strategi Komunikasi, 2007, p. 3).

Cassandra in Hafied Cangara believes, in message management techniques, communication can be considered effective, there are two models of message composing, namely: composing informative messages, and composing persuasive messages. (Cangara, Pengantar Ilmu Komunikasi, 2007, p. 116). The message formulation model is informative, devoted more at the knowledge and awareness expansion of the audience, diffuse, simple, clear, and do not use any terms.

There are four kinds of composing informative messages:

a. Space Order, which is composing messages that look at the conditions of a place or space, such as local, regional or national.

b. Time Order, that is arrangement of messages based on time or period chronologically.

c. Deductive Order, that is composing messages from general to specific topic.

d. Inductive Order, that is composing messages from specific to general topic.

Persuasive messaging models can be classified as follows:

a. Fear Appeal, that is a method of composing or conveying messages by frightening audiences.

b. Emotional Appeal, that is a method of composing or conveying messages by arousing public emotion, such as exposing issues of ethnicity, religion, discrimination, economy, etc.

c. Reward Appeal, that is a method of composing or conveying messages by making promises, such as in election campaigns.

d. Motivasional Appeal, that is a method of composing or conveying messages without promises but with psychological motivation.

e. Humorious Appeal, that is a method of composing or conveying messages with jokes so that it becomes an attraction for the public, not saturated.

Besides those techniques, to manage messages effectively, we also need to paying attention to the following points:

a. The message conveyed must be understood first, systematically.

b. Able to argue logically to support the material presented.

c. Mastering language intonation and nonverbal movements that can attract audiences.

d. Clever to spice up messages with anecdotal stories to reduce audience boredom (Cangara, Pengantar Ilmu Komunikasi, 2007, p. 118).

\subsubsection{Communication Strategy During Disaster}

Haddows and Kims in Rudianto revealed that there are 4 (four) principal foundations that can be used as a strategy in building communication during a disaster, namely:

a. Costumer Focus, that understands the information needed by customers, in this case the community and volunteers. Governments must regarding public as customers to meet their needs for information, both in 
quantity and quality related Covid-19. So, people can stay alert and not panic. A communication mechanism must be established to ensure that information is conveyed correctly and accurately.

b. Leadership commitment, leaders in emergency situations must be committed to effective communication and must be actively involved in the communication process. The public will feel safe if they see the seriousness and ability of the government in controlling the Covid-19 pandemic. Good coordination between institutions, both central and regional, is part of the leader's commitment to its citizens.

c. Situational awareness, effective communication is based on controlled collection, analysis and dissemination of information related to disasters. Principles of effective communication such as transparency and trustworthiness are the key.

d. Media partnership, television, newspapers, radio and others are very important media to convey the latest information about the proper handling of a pandemic to the public. Cooperation with the media concerns; understanding of the needs of the media with well-trained team, to cooperate with the media, to get information and share it to the public (Rudianto, 2020, p. 8).

\subsection{Aceh Government}

\subsubsection{Legal Basis}

Aceh Government is a Provincial Government within the system of The Unitary State of the Republic of Indonesia based on the 1945 Constitution of the Republic of Indonesia which organize government affairs implemented by the Aceh Regional Government and the Aceh Regional People's Representative Assembly in accordance with their respective functions and authorities. Pemerintahan Aceh (The Aceh Government) is equal to other Provincial Governments in Indonesia, a new version of Pemerintahan Provinsi Daerah Istimewa Aceh (Provincial Government of Aceh the Special Region) and Pemerintahan Provinsi Aceh (The Government of the Aceh Province). Aceh governance is carried out by the Governor as an executive instituton and the Aceh People's Representative Council as a legislative institution. The Aceh government is formed based on the Government System of the NKRI (Unitary State of the Republic of Indonesia), which according to the 1945 Constitution of the Republic of Indonesia, recognizes and respects regional government units that are special or special in nature. The constitutional journey of the Republic of Indonesia places Aceh as a regional government unit that has special authority, related to the historical unique character of Acehnese struggle, which has high resilience and fighting power. Those resilience and high fighting power comes from a way of life based on Islamic law, which rising strong Islamic culture, so that Aceh becomes one of the important capital when fighting for independence of The Republic of Indonesia, which is based on Pancasila and the 1945 Constitution. Thus, life requires the formal implementation of sharia law enforcement. The enforcement of Islamic sharia is carried out on the principle of Islamic personality for everyone in Aceh, regardless of nationality, position and status in the region.

\subsubsection{Special Autonomy of Aceh}

State recognition of the privileges and specialties of the Aceh is given through Law Number 11 of 2006 about Aceh Governance (LN 2006 No 62, TLN 4633). This Aceh Government Law is inseparable from the Memorandum of Understanding between the Republic of Indonesia and Gerakan Aceh Merdeka (Aceh Independent Movement) which was signed on August 15, 2005 and is a reconciliation towards sustainable social, economic and political development in Aceh.

Law No. 11/2006, which contains 273 articles, is the special 'Regional Government Law' for Aceh. The substance of this law, and the specificity and distinctiveness of Aceh, which forms the main framework of Law 11/2006, is mostly the same as Law No. 32/2004 on Regional Government. Therefore, Aceh is no longer depend on the Regional Government Law (for matters that have been regulated according to the Aceh Government Law).

\subsubsection{Implementation of Islamic Sharia}

Aceh Province is the only province in Indonesia that implements Islamic Sharia, which refers to the provisions of Islamic Criminal Law known as the Hukum Jinayat (Law of Jinayat). The application of Islamic Sharia is regulated in a regional regulation or Qanun of Aceh Province number 6 of 2014 concerning the Law of Jinayat.

\subsubsection{Borderline}

The outer boundaries of the Aceh region are:

a. Northern bordered Strait of Malaka. 
b. Southern bordered North Sumatera province.

c. Eastern bordered Strait of Malaka.

d. Western Northern bordered Hindia Ocean

\subsubsection{Aceh Government Structure}

The Aceh region is divided into regency and cities. Regency and Cities are part of the Provincial Region as a legal community unit, which is given special authority to regulate and manage government affairs and the interests of the local community by themselves, in accordance with the laws and regulations in the system and principles of the NKRI government based on the 1945 Constitution led by a Regent/Mayor. Regency / City is divided into Districts. A sub-district is the working area of a Head of District as an apparatus of a Regency / City, in administering District government. Districts are divided into Kemukiman. Kemukiman is a community unit under a sub-district, consisting of several gampongs, which have certain territorial boundaries, which are led by Imeum Mukim (or another name) and are directly under the Head of District Furthermore, Kemukiman is divided into Gampong. sub-district in Aceh was phased out to become Gampong (or other names) within the Regency/City. Gampong (or another name) is a legal community unit under Kemukiman and led by Geuchik (or other names) who have the right to carry out their own household affairs (humas.acehprov.go.id, 2020).

\subsection{Corona Virus Disease 2019 (Covid-19)}

Corona viruses are a group of viruses that cause the disease, ranging from mild to severe symptoms. At least, there are two types of Corona Virus that are known to cause disease, which can cause severe symptoms such as Middle East Respiratory Syndrome (MERS) and Severe Acute Respiratory Syndrome (SARS). Coronavirus Disease 2019 (Covid-19) is a new type of disease that has never been identified in humans. The virus that causes Covid-19 is called Sars-CoV-2. Corona viruses are zoonotic (transmitted between animals and humans). Research states that SARS is transmitted from civet cats to humans and MERS from camels to humans. Meanwhile, the animal that is the source of transmission of Covid-19 is still unknown (Kemenkes, 2020).

Common signs and symptoms of Covid-19 infection include acute respiratory symptoms such as fever, cough and shortness of breath. The average incubation period is 5-6 days and the longest incubation period is 14 days. Severe cases of Covid-19 can cause pneumonia, acute respiratory syndrome, kidney failure and even death. Clinical signs and symptoms reported in most cases was fever with some cases having difficulty breathing, and X-rays showed extensive pneumonia infiltrates in both lungs. (dinkes.acehprov.go.id, 2020).

Based on scientific evidence, Covid-19 can be transmitted from human to human through coughing/sneezing droplets, not through the air. People who are most at risk of contracting this disease are those who have close contact with Covid-19 patients, including those who treat Covid-19 patients. Standard recommendations for preventing the spread of infection are regular hand washing with soap and clean water, practicing coughing and sneezing ethic, avoiding direct contact with livestock and wild animals, and avoiding close contact with anyone showing symptoms of respiratory illness such as coughing and sneezing. In addition, implementing Infection Prevention and Control (PPI) while in health facilities, especially emergency units (dinkes.acehprov.go.id, 2020).

\section{Method}

\subsection{Research Type and Approach}

This research is designed as a qualitative research with a phenomenological approach, a study that describes the results of in-depth interviews with informants and observations of the subjects, about various data related to visible and invisible phenomena such as oral speech, attitudes, behavior, and facial expressions, as primary data, without operationalizing or testing the concept on the reality under study first (Kriyantono, 2006, p. 67).

In line with this definition, Bogdan and Biklen in Syukur Kholil, define the Qualitative Method as a research procedure that produces descriptive data, in the form of written or spoken words from observable people and behavior. Furthermore, Kirk and Miller, also in Syukur Kholil, define Qualitative Research as a particular tradition in social science which fundamentally relies on observing humans, within their own domain and relating to people in their language and terminology (Kholil, , 2016, p. 121).

\subsection{Research Informants}

In qualitative research, determining key sources or informants is very important, because their role is as the main resource person to obtain valid data which is sometimes concealed and closed from the research object. The key informants should be people who are considered capable and has the capacity to provide information 
related to the focus of research conducted. Research informants can come from internal circles of the bureaucracy or regular community, they are:

a. Bureau chief of Public relations and Regional secretariat protocol, Aceh.

b. Head of Aceh Communication, Informatics and Encoding Department.

c. Head of Health Department.

d. Head of Aceh Disaster management Agency.

e. Academics and Observers in Communication Field.

f. Academics and Observers in information Technology and Communication Field.

\subsection{Data Source}

All data obtained in this study consisted of two sources, namely:

a. Primary data sources, which are obtained from the results of interviews (indept interviews) with the speakers, namely a number of key informants and Focus Group Discussion participants (who will be selected), direct observation of research subjects as well as other important data and information obtained from the field.

b. Secondary Data Sources, obtained from official manuscript archives (official Aceh government letters), textbooks, theoretical assumptions, journals, papers, research reports, proceedings, photos and video documentation, websites, and press scrapbook.

\subsection{Collecting Data Instruments}

The collecting data instruments used are:

a. Interview Guidelines as a guideline for data collection through in-depth interviews with informants, in this case the author uses semi-structured interview guidelines, that is interview guidelines that are arranged in detail but there is still a chance to dig deeper into the data from informants.

b. Observation Guide as a tool in data collection activities by observation to research subjects. Observation in qualitative research only is made in the form of the outlines of the main concepts that will be observed.

c. Audio Visual tools to capture sound and images as supporting evidence of research results.

\subsection{Data Collection}

Data collection in this study was carried out using multi-methods, as follows:

a. In-depth Interviews is the process of collecting data through verbal questions and answers between researchers and sources. This type of in-depth interview is also called 'intensive interview' because it is carried out more than once, interviews are conducted repeatedly right on the location and in a relatively long duration if compared to regular interviews but are still focused on relevant data only.

b. Observation is the method of collecting data by observing with the eyes and other senses. In observation, the researcher does not only use the eyes, but always connects what he sees with what is received by the other senses.

c. Documentation study is collecting data by reviewing documents, such as legal products and official scripts that have been published by the Aceh Government, as well as text books, journals, proceedings, press scrapbook, websites, and audio-visual recordings that have been produced and published by the Aceh Government, related to the handling Covid-19 in Aceh 2020.

\subsection{Data Processing and Analysis}

In this study, the data obtained were analyzed using a qualitative approach, which consists of, Constant Comparative and Domain Analysis. Before applying these two data analysis techniques, the data interpretation process was carried out in accordance with the theory to make it easier to understanding and arguing the existing data. This data analysis process starts from empirical facts called Data Collection, then it is included in the data classification by looking at general characteristics (categorization), then giving it meaning or interpretation. 


\section{$\underline{\text { Empirical Facts }}$}

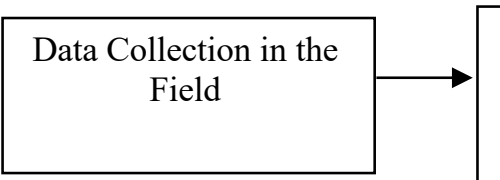

Conceptual Level

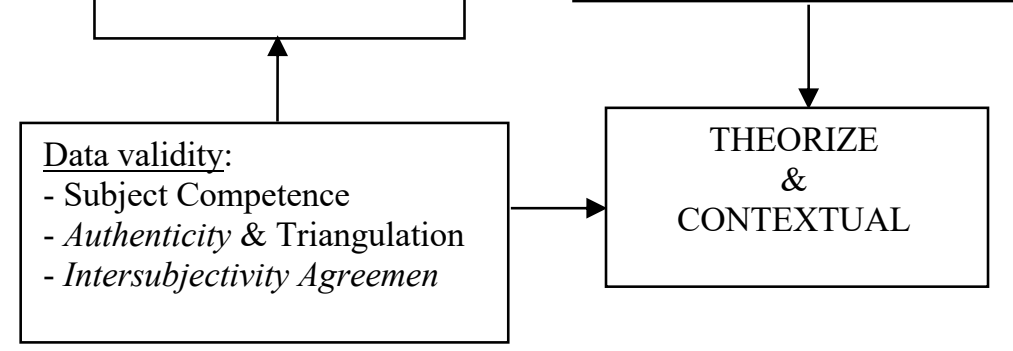

Pic: Qualitative Data Analysis Process (Kriyantono, 2006, p. 197)

The last stage is the conclusion, which is a process of formulating the final results of research, after all the processes, including the processing and analysis, and relate it to the theory, as part of the inductive method in the tradition of qualitative approach (Kriyantono, 2006, pp. 196-200).

\section{Results and Discussion}

\subsection{Communication Strategy of Aceh Government to Handling Covid-19 Pandemic}

Based on data and information from in-depth interviews with several key informants, observations, and the documents published by the Aceh Government and Mass Media related to Covid-19 in Aceh Province, those are classified and processed according to the chosen technique. So, the results shows several Communication Strategies implemented by the Aceh Government in handling the Covid-19 pandemic. From these Communication Strategies, authors found 4 (four) dominant Communication Strategies, which are new, distinctive and innovative strategies: Motivational Communication Strategies, Quick Reaction Strategies, Leadership Commitment Communication Strategies and Mass Communication Strategies.

\subsubsection{Motivational Communication Strategy}

A psychotherapist who is well known with his books about spirituality, once reminded us that in handling a pandemic in the world, the number of victims could be five times more if there is fear. One thousand people became victims because of illness, while four thousand more became victims because of panic. (who.com, 2020). Reflecting on this, communication is the most important thing in dealing with a pandemic. Public trust needs to be built and maintained, in order to reduce panic among the society, handling process could run smoothly. Therefore, the Government must show their seriousness, readiness and ability to handle this outbreak. Perceptions about readiness and seriousness of Aceh Government need to be conveyed through a comprehensive and periodic explanation to the public. Describe what the Government has done and will do. The Aceh Government implemented this communication strategy very well during Covid-19 pandemic. Even Government, through the Covid-19 Accelerated Handling Task Force, invited the public to unite to fighting Covid-19. The government and citizens must work together in handling Covid-19, both in preventing and handling act. In an interview, the Bureau chief of Public relations and Regional secretariat protocol said that Aceh Government through several Regional Apparatus Organizations (OPD), which are members of the Covid-19 Accelerated Handling Task Force, motivated public to be calm but still wary, and understand what they have to do in their circle. The communication strategy with motivational techniques is also aimed to build people's perceptions that the State (Aceh Government) is responsive in preventing and controlling the Covid-19 pandemic (KaroHumpro, 2020). Likewise, the solidarity of the Aceh Government with their colleagues (Forkopimda), showing their concern for the community through several appeals that were signed jointly, carried out by all Acehnese people in the face of the Covid-19 pandemic. On March 19, 2020, Forkopimda Aceh issued an appeal regarding the Acceleration and Anticipation of the Spread of Covid-19 in Aceh (humas.acehprov.go.id, 2020). This joint appeal was widely publicized to the Acehnese people through the Mass Media, as well as the entire Government Network, until all gampong throughout Aceh. On March 29, 2020, Forkopimda Aceh also issued a Joint Decree regarding the implementation of the curfew. (bpba.acehprov.go.id, 2020). This shows the solidarity of the leaders, motivating society, so that people feel comfortable, feel cared and protected during this pandemic. This motivational communication strategy has got support from Acehnese. The citizens will voluntarily obey all appeals during the Covid-19 pandemic. 


\subsubsection{Quick Respon Strategy}

Long before the Central Government formed Covid-19 Accelerated Handling Task Force on the central level in April 2020, the Aceh Government on 26 January 2020 had established an Alert Post for handling Covid-19 in Aceh Province first, which is based at the Aceh Social Service. (KadisInfokom, 2020). The first Quick Response of the Aceh Government by the Posko Siaga (Post Alert) are recorded all Aceh's students and residents in Wuhan and send them to the Ministry of Foreign Affairs of the Republic of Indonesia in Jakarta. Then on the recommendation of the Indonesian Ministry of Foreign Affairs on January 27, 2020, the Aceh Government sent logistical support to Acehnese students and residents in Wuhan. (serambinews.com, 2020).

During an interview with the Head of Aceh Information and Communication Department, he said, on the same day with delivery of logistical support to students and residents of Aceh in Wuhan, the GoA did appointments of two (2) Hospital for referral patients Covid-19, the Zainal Abidin hospital in Banda Aceh and Cut Meutia Hospital in Lhokseumawe (KadisInfokom, 2020). Another step taken by the Aceh Government is trying to return Acehnese students and residents in Wuhan to Indonesia. From 65 students throughout China, the Central Government of Indonesia evacuated 13 students from Wuhan to Natuna. 5 (five) people were facilitated to return to Aceh, while 45 other residents were already in Aceh (antaranews.com, 2020). Furthermore, prior to an order from the Central Government, using the Emergency Response Fund, the Aceh Government ordered various Covid-19 referral hospital facilities and Personal Protective Equipment (PPE) for Health Workers. Besides health facilities and equipment, the Emergency Response Fund is also used to provide basic foodstuffs for families of Covid-19 patients and health workers, even though at that time there was still no positive Covid-19 case in Aceh.

These various quick responses from the Government of Aceh were well publicized by various media, under the coordination of the Aceh Public Relations and Regional secretariat protocol and Aceh Information and Communication Department. This quick response received appreciation from the Acehnese, some of the people's representatives who served in the Aceh People's Representative Council (DPRA) and also from the Central Government through the Ministry of Foreign Affairs of the Republic of Indonesia.

\subsubsection{Leadership Commitment Strategy}

Leaders who play a role in the emergency response must have a strong commitment to actively take part in every activity to handle Covid-19. The public will feel calm if they see the seriousness and ability of the leaders in controlling the Covid-19 pandemic. Good coordination and cooperation between agencies is part of the leader's commitment to their citizens.

During an interview with the Head of the Aceh Head of Health Department, he said that the Deputy Governor of Aceh, Mr. Ir. H. Nova Iriansyah, MT, who currently serves as Acting Officer (PLT) for the Governor, carried out this Communication Strategy very well. He handled directly various activities related to the handling of Covid-19. This is the leadership's commitment to solving the problem as well as motivating the field workers.

Praying together for students and Acehnese in Wuhan that was held on February 5, 2020 at the Hall of Vice Governor Office shows the concern and seriousness of the leader. When the students and Acehnese returned from Wuhan on February 16, 2020, the Acting Officer (PLT) for the Governor welcomed them at Sultan Iskandar Muda Airport - Banda Aceh (antaranews.com, 2020). Furthermore, the Acting Officer (PLT) for the Governor also showed his commitment by attending directly to review the readiness of the Zainal Abidin Hospital in Banda Aceh and the Cut Mutia Hospital in Lhokseumawe as the Covid-19 Reference Hospital (antaranews.com, 2020). On March 29, 2020, the Acting Officer (PLT) for the Governor also sent a letter to all special health workers whose handle covid-19 patients. The letter contains motivation and appreciation for their dedication in carrying Covid-19 patients (ajnn.net, 2020). To improve the quality and quantity of handling of Covid-19 patients, on March 31, 2020, the Aceh Governor PLT came to inaugurate the Pinere Outbreaks Room at Zainal Abidin Hospital, Banda Aceh (m.kumparan.com, 2020). A day later, on April 2, 2020, the Acting Officer (PLT) for the Governor inaugurated an accommodation for the Medical Team that handles Covid-19 patients (beritasatu.com, 2020). Furthermore, on April 8, 2020, the Acting Officer (PLT) for the Governor was also came to inaugurate the Special Polyclinic for Infectious Diseases at Zainal Abidin General Hospital in Banda Aceh. (kasadar.com, 2020). At the same time, 3 out of 4 positive covid-19 patients who were treated in the RSUZA isolation room were declared cured (m.liputan6.com, 2020).

This on-the-spot activity was not only carried out by the Aceh Acting Officer (PLT) for the Governor, but also his wife as the Chairperson of the Aceh Provincial TP PKK (The Team for Mobilizing Family Empowerment and Welfare), Dr. Diah Nova Iriansyah to pay attention to women, mothers and children in 
facing Covid-19 pandemic especially in Aceh. A support from the Government was directly delivered (symbolic) by the Chairperson of the PKK Aceh to the entitled people. This is one of the communication strategies of the Aceh Government in dealing with the Covid-19 pandemic by giving serious attention and strong commitment to the citizens.

\subsubsection{Mass Communication Strategy}

Mass Communication Strategy means a media partnership strategy, such as; Television, newspapers, radio and others are very important media to convey information about the real updates about handling Covid-19 to the public. Collaboration with the media concerns an understanding of data and information that can be shared with the public. The Aceh Government through the Aceh Bureau chief of Public relations and Regional secretariat protocol, the Aceh Information Communication Service, and the Spokesperson for the Covid-19 Accelerated Handling Task Force have intensive communication with the media crew. Provision of fast and accurate 'data and information' about Covid-19 data updates in Aceh. Media crews easily access every updates of Covid-19 and put it on the news for public consumption.

The target audience can be reached through various channels in Aceh, either through mainstream media, social media, online media daily or through communication networks. The media used by the Aceh government to convey data and information related to developments in the handling of the Covid-19 pandemic are: The official website of the Aceh Government, namely acehprov.go.id, television, print media, online media, radio, SMS gate a way, social media, Local Government (Regency / City) information networks, inter-school information networks, youth / religious / political organization networks and other informal networks.

With this strategy, most of the activities of the Aceh Government in dealing with Covid-19 have been completely recorded in mass media reports, and finally consumed by the public. With this 'Media Partnership' strategy, the Aceh Government hopes that all information regarding the handling of Covid-19 can become a routine agenda for the media in Aceh. Every day, even at any time, the media is expected to be able to inform and educate the public about how to deal with the Covid-19 pandemic without feeling worried but still wary. This Media routine expected to become a routine agenda for Acehnese so people will share and educate each other for healthy habits during the pandemic. (KadisInfokom, 2020).

4.2 Challenges for The Aceh Government in Implementing the Communication Strategy While Handling the Covid-19 Pandemic

Challenges for the Aceh Government in implementing a Communication Strategy in handling the Covid-19 Pandemic in Aceh are:

\subsubsection{Accessibility}

Aceh Province has these following accesses:

a. Access to air traffic, Aceh has 13 airports (airports) with 2 (two) International Airports and 11 (eleven) Domestic Airports.

b. Access to sea traffic, Aceh has 18 (eighteen) ports classified as 8 (eight) Ferry Ports and 10 Export Import Seaports.

c. Access to land traffic, Aceh has 3 entrances that are directly adjacent to North Sumatra Province, namely Aceh Tamiang District - Langkat Regency, Aceh Tenggara District - Karo Regency and Aceh Singkil Regency - Dairi Regency (dishub.acehprov.go.id, 2020).

These accesses provide opportunities for citizens outside of Aceh to enter Aceh Province, both legally and illegally (especially from neighboring Malaysia).

\subsubsection{Social-Economy}

a. The Covid-19 health protocol in the form of Social Distancing and Physical Distancing and Stay at Home which is campaigned by the Government is estimated to be difficult to implement in Acehnese society because majority of Acehnese economic conditions are still in the category of Small and Medium Enterprises (perindag.acehprov.go.id, 2020).

b. There are a large number of Acehnese who have status as migrant workers abroad, especially in Malaysia, as well as those who work and doing business in other provinces outside Aceh (disnakermobduk.acehprov.go.id, 2020).

\subsubsection{Socio-Culture}


a. Woe u gampong, the tradition of going home or returning to the village during the first day of Ramadan worship and Eid celebration.

b. Listening Culture, in consuming information, the Acehnese prefer to listen. Written information about the health protocol for handling Covid-19 makes it more difficult for them to adjust.

c. Myth, some Acehnese figures and people believe that Covid-19 is a kind of ghost (ta-uen) that will disappear with a ritual of driving out demons.

d. Speculation, has spread among some public figures that Covid-19 is a type of biological weapon produced by certain countries to control and destroy a certain country to dominating the world politically and economically (m.detik.com, 2020).

e. The aftermath of the long conflict and the earthquake and tsunami disaster, has changed the character, attitudes and behavior of the Acehnese to be individualist, hedonist and fragmatis. (Abdullah , 2006, p. 131).

\subsubsection{Spiritualism}

a. The Covid-19 health protocol, which requires residents to be at home, has led to the wrong perception of some Muslim religious teachers and this has greatly affected their followers. The protocol is perceived as prohibiting worship in mosques or Meunasah (smaller place for praying), even though it is only a limitation in the way of praying

b. Some circles of society perceive that Covid-19 is the "Army of God" who will scorch the evil on earth and people who worship will be saved from it. This makes some people feel normal and do not care about what is happening.

c. Some other Acehnese think that Covid-19 is a havoc that must be fought by increasing worship and 'dzikir' (remember God) rituals together by gathering and involving a lot of people.

d. Because of the religiousness, the Acehnese are easily offended if there are new rules that contrary to the religious rituals (m.liputan6.com, 2020).

\subsubsection{Local-Politics}

The political relationship between the Aceh Government as the Executive and the Aceh People's Representative Council (DPRA) as the Legislative is not harmonious nowadays. This is greatly affected the accuracy and speed of every decision and action of Aceh Government in handling Covid-19 which often provoked criticism from the DPRA as the legislature (m.republika.co.id, 2020). Excessive and political criticism from some DPRA sembers has obstructed the Aceh Government's steps in dealing Covid-19 Pandemic. The problems that appeared in the DPRA Special Committee (Pansus) sessions which discussed the Supervision of Covid-19 Handling Funds (refocusing) eventually led to the submission of Interpellation Rights by DPRA (news.detik.com, 2020). What has been done by the DPRA was challenge for the Aceh Government in fast handling of Covid-19 in Aceh.

\section{Conclusion}

The small number of residents who have become victims of the Covid-19 pandemic in Aceh is considered as the success of Aceh Government in dealing Covid-19. The handling efforts included prevention and control of the Covid-19 pandemic. This activity was well communicated through Communication Strategies so that the public can supported and played an active role in overcoming the pandemic.

From a series of Communication Strategies implemented it can be concluded that there are 4 (four) Communication Strategies that are classified as new and distinctive or innovative strategies implemented by the Aceh Government, namely: Motivational Communication Strategy, Quick Response Strategy, Leadership Commitment Communication Strategy and Mass Communication Strategy.

The challenges faced by the Aceh Government, in implementing communication strategies in handling the Covid-19 pandemic, are very diverse, namely: Regional Accessibility, Socio-Economic, Socio-Cultural and Religious as well as Local Political Dynamics. These challenges have more or less affected the acceleration of the handling of the Covid-19 pandemic in Aceh Province.

Innovative communication strategies implemented by the Aceh Government during the Covid-19 pandemic, so that they can be applied to handling emergency disasters or other outbreaks in Aceh Province in the future. The aforementioned innovative strategies should be put in writing, so that other Provinces can learn / imitate them, which have similar characteristics with Aceh Province. 


\section{References}

Abdullah, I. (2006). Rekonstruksi dan Reproduksi Kebudayaan. Yogyakarta : Pustaka Pelajar.

aceh.tribunnews.com. (2020, 4 23). Retrieved from https://aceh.tribunnews.com/2020/04/23/ idiingatkanpotensi-serangan-tahap-ii

aceh.tribunnews.com. (2020, 4 23). Retrieved from https://aceh.tribunnews.com/2020/05/29/suratipemerintah-aceh-pusat-minta-aceh-bagi-pengalaman-cara-tangani-covid-19

ajnn.net. (2020, 3 29). Retrieved from http://www.ajnn.net

antaranews.com. (2020, 2 16). Retrieved from http://.www.antaranews.com

antaranews.com. (2020, 3 12). Retrieved from http://www.antaranews.com

antaranews.com. (2020, 3 12). Retrieved from http://.www.antaranews.com

beritasatu.com. (2020, 4 2). Retrieved from http://www.beritasatu.com

bpba.acehprov.go.id. (2020, 4 23). bpba.acehprov.go.id. Retrieved from bpba.acehprov.go.id: http://www.bpba.acehprov.go.id

Cangara, H. (2007). Pengantar Ilmu Komunikasi. Malang: Rajawali Press.

Cangara, H. (2007). Perencanaan dan Strategi Komunikasi. Malang: Rajawali Press.

Chrosky , M. a. (2020). The effect of Disorganization and Nonfluency on Attitude Change and Source Credibility . In A. Masduki, Krisis Komunikasi dalam Pandemi Covid-19 (p. 62). Yogyakarta: Buku Litera.

covid19.go.id. (2020, 4 23). Retrieved from https://www.covid19.go.id

dinkes.acehprov.go.id. (2020, 8 31). Retrieved from https://www.dinkes.acehprov.go.id

dishub.acehprov.go.id. (2020, 5 31). Retrieved from https://www.dishub.acehprov.go.id

disnakermobduk.acehprov.go.id. (2020, 5 31). Retrieved from https://www.disnakermobduk.acehprov.go.id

Effendi, O. U. (1990). Komunikasi : Teori Ilmu dan Praktek. Bandung: Remaja Rosdakarya.

Fajar, M. (2009). Ilmu Komunikasi : Teori dan Praktek. Jakarta: Graha Ilmu dan UMB.

Haddows, K. a. (2020). Disaster communication. In Rudianto, Krisis Komunikasi dalam Pandemi Covid-19 (p. 7). Yogyakarta: Buku Litera.

humas.acehprov.go.id. (2020, 4 23). Retrieved from https://www.humas.acehprov.go.id

KadisInfokom. (2020, 1 27). Retrieved from harianrakyataceh.com: http://www.harianrakyataceh.com

KaroHumpro. (2020, 6 2). Motivasi untuk Masyarakat. (Penulis, Interviewer)

kasadar.com. (2020, 4 4). Retrieved from http://www.kasadar.com

Kemenkes. (2020). Pedoman Pencegahan dan pengendalian Covid-19. Jakarta: Kemenkes RI.

Kholil, , S. (2016). Syukur Kholil, Metode Penelitian Komunikasi. Medan: Perdana Publishing.

Kholil, S. (2007). Komunikasi Islam. Bandung: Cita Pustakamedia.

Kriyantono, R. (2006). Teknik Praktis Riset Komunikasi. Jakarta: Kencana Predana Media Grup .

m.detik.com. (2020, 4 4). Retrieved from https://www.m.detik.com/2020/04/04/viral-bupati-pidie-bicaravirus-corona-senjata-biologis-ini-penjelasan-pemkab

m.kumparan.com. (2020, 3 31). Retrieved from http://www.m.kumparan.com

m.liputan6.com. (2020, 4 4). Retrieved from http://www.m.liputan6.com

m.liputan6.com. (2020, 5 31). Retrieved from https://m.liputan6.com/regional/read/4212272/aceh-viruscorona-dan-upaya-mencari-tuhan-di-tengah-kerumunan

m.republika.co.id. (2020, 8 11). Retrieved from http://www.m.republika.co.id

$\begin{array}{lllll}\text { nasionalkompas.com. } & (2020, & 4 & 23) . & \text { Retrieved }\end{array}$ https://www.nasionalkompas.com/read/2020/03/04/08051361/ pengumuman-mendadak-jokowiyang-kejutkan-pasien-positif-corona

news.detik.com. (2020, 9 11). Retrieved from http://www.news.detik.com

perindag.acehprov.go.id. (2020, 5 31). Retrieved from https://www.perindag.acehprov.go.id 
Rudianto. (2020). Komunikasi dalam Penanggulangan Pandemi Covid-19 di Indonesia. In F. Junaedi, Krisis Komunikasi dalam Pandemi Covid-19 (p. 8). Yogyakarta: Buku Litera.

serambinews.com. (2020, 1 27). Retrieved from http://www.serambinews.com

who.com. (2020, 8 31). Covid-19. Retrieved from Covid-19: www.who.int/emergencies/diseases/novelcorona-virus-2019

worldometers. (2020, 8 31). Corona Virus. Retrieved from Corona Virus: https://www.worldometers.info/coronavirus/? 